\title{
SOCIAL AND ECONOMIC CONDITIONS OF TOURISM ACTIVITY OF STUDENTS IN KRAKOW
}

\begin{abstract}
Research has identified conditions of tourism activity of university students, with a particular focus on the analysis of certain social and economic factors. A hypothesis (H1) has been formulated that there is a significant relation between selected social and economic factors and the level of tourism activity of examined students from the academic centre of Krakow. Another hypothesis (H2) that has been verified states that economic factors are of the greatest influence on participation in tourism. Research was conducted with the use of quantitative and qualitative methods. Quantitative research used the method of diagnostic survey with 521 subjects who were students of randomly chosen Krakow universities. Qualitative research was based on the story-telling method. This part of research took the form of detailed interviews with students who demonstrated varied level of activity in tourism. Detailed interviews were conducted with four students of each of the assumed types. The statistical analysis was based on statistical methods (chi-squared test of independence, Tschuprow's $\mathrm{T}$ measure of association), which enabled the author to adopt $\mathrm{H} 1$ hypothesis and forced her to reject $\mathrm{H} 2$ hypothesis.

Keywords: determinants of tourist activity, tourist activity, students, student tourism, storytelling method
\end{abstract}

\section{INTRODUCTION}

Despite occasional periods of crises, tourism has experienced invariable boost. In accordance with the report of the United Nations World Tourism Organisation (UNWTO), international tourism increased globally from 25 million in 1950 to 278 million in 1980, 674 million in 2000 and 1186 million in $2015^{3}$. The group of travellers includes young people who are students and who belong to the most active social group in terms of tourism in the contemporary world. It is a very active and mobile group characterised by curiosity of the world and having no language barriers. Their participation in tourism is of diverse nature as it combines their willingness to get to know the world and people, to learn, to volunteer, to work and to experience adventures. Young travellers are often pioneers in the discovering of new destinations. It is a good idea to aim at getting to know tourist behaviours from the scientific perspective, including the very fact of practising tourism by a chosen age group. This may be useful as it is the young people who set new trends and build the future tourism market. The article emphasises the uniqueness of the analysed social group in case of which it seems that the common conviction that economic

\footnotetext{
${ }^{1}$ Anna Delekta, PhD, Department of Tourism and Regional Studies, Institute of Geography, Pedagogical University of Cracow, Poland - Cracow, ul. Podchorążych 2, 30-084 Kraków, tel. (012) 662 6260, corresponding author: e-mail: adelekta@up.krakow.pl

${ }^{2}$ JustynaStecko, PhD, Rzeszow University of Technology, Faculty of Management, Institute of Humanities Sciences, jstecko@prz.edu.pl

${ }^{3}$ UNWTO, Tourism Hightlights, Edition 2016.
} 
factors are of the greatest influence on tourism activity is not confirmed. Therefore, focus is laid on the presentation of the most important economic and social conditions of tourism activity as well as verification of whether they have a considerable impact on the examined phenomenon. Only then will it be possible to go further to the most important task which involves determining the strength of the relationship between the analysed variables. This will contribute to answering one of the most frequent questions in the literature on the subject: Do economic factors have the greatest influence on participation in tourism?

\section{MATERIAL AND METHODS}

Research presented in this paper is an element of a research project aimed at observing the phenomenon of tourism activity of young people, with a particular focus on students at the largest academic centres in Poland. The research is concentrated on seeking and analysing factors which condition participation of the most active social group in tourism. When it comes to various groups that determine the examined phenomenon, this paper is focused only on the analysis of some economic and social factors.

Research was conducted with the use of quantitative and qualitative methods. Both approaches were treated as mutually complementary research strategies. The subjects chosen for qualitative research included students who were very active in tourism (who travelled several or even a dozen or so times a year), exhibited average tourism activity (travelled once to four times a year) or little activity or passivity in this respect. Four individuals of each type were analysed. Interviews based on the assumptions of storytelling were carried out with these subjects.Storytellingis based on the analysis of narrations created by subjects and is a natural way for the sharing of human experience. Boje $^{45}$ claims that research by collecting stories is less intrusive and less susceptible to the disturbance of the very research process. Subsequently, the obtained narrations were analysed in depth in order to learn about and understand tourism behaviours of the subjects, their causes and inhibitors.

Quantitative research used the method of diagnostic survey on a population of students of randomly chosen Krakow universities. Research material was collected during the period from October to December 2015. Questionnaires used included questions which helped learn the analysed phenomenon as well as its characteristics in the examined population. Material collected from 521 respondents was juxtaposed, analysed and elaborated in statistical terms.

\section{CONCEPT OF TOURISM ACTIVITY}

Activity belongs to the essence of life. Human is connected with his or her surroundings by nature. Human existence is based on the constant regulation of relations with the world. And this regulation is activity. The level and direction of activity depends on the individual's situation, his/her internal state and the state of his/her surroundings. K.

\footnotetext{
${ }^{4}$ Boje, D. M., The Storytelling Organization: A Study of Story Performance in an Office-Supply Firm, Administrative Science Quarterly, 36(1), 1991, s.106-126.

${ }^{5}$ Boje, D. M. i Tourani, N. Storytelling, czyli o materialności praktyk opowiadania", [in:] Badania jakościowe. Podejścia i teorie, Jemielniak, D., Wydawnictwo Naukowe PWN, Warszawa 2012.
} 
Łopaciński ${ }^{6}$ claims that "[...] individual's activity should be understood as a certain continuum between a complex of behaviours directed at changes in the surroundings and in oneself and passive subjection to the influence of the environment and potential changes occurring in it and internal conservatism." Man has shown various types of activity since the beginning of their existence. Tourism is classified as a type of activity. In various classifications of human activity, tourism activity is either omitted or incorporated into more broadly defined types of human activity, e.g. recreational activity. Skorny ${ }^{7}$ belongs to a group of few authors who mention tourism activity as one of different types of human activity (social, scientific, educational, cultural, artistic, production, entertainment, self-service and other).

Now we can attempt to explain what tourism activity is. There are not too many definitions of the concept in Polish and foreign literature on the subject and if they exist they do not always coincide with one another. In Poland, the concept refers almost entirely to activities taken by people. In the literature in the English languages, tourism activity is more frequently used within the meaning of business activity in the field of tourism than with reference to human behaviours in tourism. The view of T. Chudoba ${ }^{8}$ is worth attention here. He believes that "the world of tourism reality" is the result of activity of four groups of people from which emerge four kinds of processes:

-activity of tourists which corresponds to the practising of tourism.

-activity of individuals who organise tourist events or co-participate in their organisation, which corresponds to the organisation of tourism,

-activity of service providers which corresponds to the provision of services to tourists,

-activity of the creators of background tourism facilities which corresponds to the formation of components of material tourism background ${ }^{9}$.

Łopaciński $^{10}$, Boyer ${ }^{11}$, Borkowski ${ }^{12}$, Alejziak ${ }^{13}$ and Delekta ${ }^{14}$ claim that three journey durations can be distinguished in tourism activity: imagined journey (before the journey), experienced journey (during the journey), extended journey (after the journey). Therefore, it can be said that tourism activity includes "all activities connected with the preparation and practising of tourism as well as various forms of experiencing it" "15. All of the authors mentioned above agree that the practising of tourism is the most important manifestation

${ }^{6}$ Łopaciński K., Poziom aktywności turystycznej studentów [in:] Społeczno-pedagogiczne problemy turystyki, MalinowskiJ. A. (ed.), Instytut Turystyki, Warszawa 1988.

${ }^{7}$ Skorny Z., Mechanizmy regulacyjne ludzkiego działania, Wydawnictwo Naukowe PWN, Warszawa 1989.

${ }^{8}$ Chudoba T., Wprowadzenie do teorii turystyki, Wydawnictwo AWF, Warszawa 1998.

${ }^{9}$ Ibidem.

${ }^{10}$ Łopaciński K., Aktywność turystyczna młodzieży akademickiej, Problemy Turystyki nr 2, Warszawa 1986.

${ }^{11}$ BoyerM., Le tourisme, PressesUniversitaires de Lyon, Lyon 1999.

${ }^{12}$ Borkowski K., Pilot a grupa [in:] Kompendium pilota wycieczek, Kruczek Z. (ed.), Wydawnictwo Proksenia, Kraków 2000.

${ }^{13}$ Alejziak W., Determinanty i zróżnicowanie społeczne aktywności turystycznej, Wydawnictwo AWF, Kraków 2009.

${ }^{14}$ Delekta A., Determinanty aktywności i destynacji turystycznych studentów dużego i małego ośrodka akademickiego, Wydawnictwo Naukowe Uniwersytetu Pedagogicznego, Kraków 2013.

${ }^{15}$ Łopaciński K., Aktywność turystyczna..., op.cit. 
of tourism activity, so research they undertake and conduct is mainly focused on the analysis of the experienced journey. This approach is also adopted in this paper.

\section{DETERMINANTS OF TOURISM ACTIVITY}

Man's tourism activity depends both on internal and external factors. This paper tackles mainly exogenous conditions. It does not result from lesser importance of internal conditions but from the concept adopted for this paper. Internal conditions include, most of all, needs, motives, attitudes, aspirations or values associated with tourism. There are numerous external conditions of tourism activity and they are quite a difficult subject of research due to their multitude, diversified nature and power of impact. Considering the classifications of tourism activity conditions found in literature and results of qualitative research, the most important external factors which determine the activity include:

-economic factors

-social factors

-demographic factors

-geographic factors

-technological factors

-health factors

-free time

-other factors, e.g. political factors, supply of tourism, experience in tourism, fashion, mass media, tourism marketing.

This study analyses two economic factors which may have an influence on tourism activity of students. The first of them is the student's financial situation. This includes funds received from parents and other family members as well as money earned on their own based on employment contracts, mandate contracts, etc. The second one is the economic situation of the respondent's family. When it comes to social determinants of tourism activity of students, on the basis of qualitative research results, the frequency of journeys of the subjects with their family and with school class that occurred in the past at various levels of education were selected. The third analysed social factor is the affinity with organisations involved in tourism. Their importance is emphasised in literature, for example in Wartecka-Ważyńska ${ }^{16}$. Other groups of factors will be analysed in a different paper.

\section{ECONOMIC CONDITIONS OF TOURISM ACTIVITY}

Economic potential of an individual determines to a large extent the consumption of goods and tourism services. Macroeconomic analyses show that a high level of economic development in a given country is closely correlated with considerable tourism activity of its citizens. A high level of tourism activity is one of the elementary characteristics of economically developed societies. Urry ${ }^{17}$ writes that "[...] being a tourist belongs to the determinants of being modern. Going nowhere is like having no car or beautiful house. Tourism has become a symbol of status in a contemporary society [...]". The dependence of tourism development on economic development belongs to the elementary laws of economic knowledge concerning the phenomenon. Thus, on the basis of economic

\footnotetext{
${ }^{16}$ Wartecka-Ważyńska A., Rola wybranych organizacji społecznych w kształtowaniu aktywności turystycznej młodzieży, Turystyka i hotelarstwo, nr 8, 2005.

${ }^{17}$ Urry J., Spojrzenie turysty, Wydawnictwo Naukowe PWN, Warszawa 2007.
} 
development level, one can precisely forecast the development of tourism consumption ${ }^{18}$.This suggests that the level of tourism activity is usually lower in poorly developed countries than in highly developed ones. Expenses of residents of thirty main emission areas (the richest countries) on tourism constitute $92 \%$ of all tourism expenses worldwide and the share of the first ten countries reaches $66 \%{ }^{19}$. According to $\mathrm{H}$. Wasiak $^{20}$, the level of participation in tourism and recreation is the function of social and economic development. The level of income definitely has an influence on tourism activity. After all, tourism demand and market behaviour of consumers are affected by the income of the population as well as the prices of goods and tourism services. These factors are the elementary parametric economic instruments which determine consumer decisions, determine the framework of these decisions and choice directions ${ }^{21}$. Relationships between participation in tourism as well as income and prices are in accordance with elementary laws of economy. Namely, the higher the income, the greater the level of tourism activity. The rule is confirmed in research carried out by Różycki ${ }^{22}$ among young people from Krakow's secondary schools. The research has shown that young people from wealthy families more frequently take up tourism activity that those from families of a lower material status. The research has shown that the financial factor influences tourism. Based on this, it may be concluded that also students from wealthy environments have easier access to goods and tourism services.

A decision was made to verify if the economic rules described above are also valid in case a consumer is a young person studying at a higher education institution. Student's financial situation and material standing of student's family were chosen as economic factors based on qualitative research. Two independent variables were juxtaposed with the level of subject's tourism activity. The results are presented in tables 1 and 2. One can note the existence of a statistically significant dependence both between the material situation of the subjects and their tourism activity as well as between the economic standing of the subject's family and his/her level of participation in tourism.

\footnotetext{
${ }^{18}$ CooperC., Fletcher J., Gibler D., Wanhill S., Tourism Principles and Practice, Pitman Publishing, Surrey, 1993.

${ }^{19}$ Alejziak W., op. cit.

${ }^{20}$ Wasiak H., Czynniki ksztattujące konsumpcje $w$ dziedzinie turystyki, wypoczynku i innych form rekreacji w uktadach regionalnych, Prace Naukowe nr 130 AE weWrocławiu, Wrocław 1978.

${ }^{21}$ Andrykiewicz-Feczko Z., Psychospołeczne podstawy wartościowania cech jakości produktu, Raport nr III.41 z badań na temat „Relacje między jakością towarów rynkowych a potrzebami konsumentów", Kraków 1986.

${ }^{22}$ Różycki P., Determinanty aktywności turystycznej młodzieży, Problemy Turystyki, nr 1-4, 2006.
} 
Table 1. Student's material situation and travels during the previous year (with accommodation for at least one night)

\begin{tabular}{|c|c|c|c|c|c|c|c|c|}
\hline \multirow{3}{*}{$\begin{array}{c}\text { Material } \\
\text { situation } \\
\text { of the examined } \\
\text { student }\end{array}$} & \multicolumn{8}{|c|}{ Travels during the last year } \\
\hline & \multicolumn{2}{|c|}{ None at all } & \multicolumn{2}{|c|}{ Once or twice } & \multicolumn{2}{|c|}{$\begin{array}{l}\text { Multiple } \\
\text { times }\end{array}$} & \multicolumn{2}{|c|}{ Total } \\
\hline & $\mathrm{N}$ & $\%$ & $\mathrm{~N}$ & $\%$ & $\mathrm{~N}$ & $\%$ & $\mathbf{N}$ & $\%$ \\
\hline Good & 18 & 6.4 & 110 & 39.1 & 153 & 54.4 & 281 & $\mathbf{5 3 . 9}$ \\
\hline Average & 21 & 9.9 & 86 & 40.6 & 105 & 49.5 & 212 & 40.7 \\
\hline Poor & 5 & 17.9 & 17 & 60.7 & 6 & 21.4 & 28 & 5.4 \\
\hline Total & 44 & 8.4 & 213 & 40.9 & 264 & 50.7 & 521 & 100 \\
\hline $\begin{array}{c}\text { Chi-squared } \\
\text { test }\end{array}$ & \multicolumn{8}{|c|}{$\mathrm{df}=4, \mathrm{p}=0.01$} \\
\hline
\end{tabular}

Source: Author's elaboration based on the conducted research

Table 2. Economic situation of the subject's family and travels during the previous year (with accommodation for at least one night)

\begin{tabular}{|c|c|c|c|c|c|c|c|c|}
\hline \multirow{2}{*}{$\begin{array}{c}\text { Economic } \\
\text { situation of the } \\
\text { family } \\
\text { of the examined } \\
\text { student }\end{array}$} & \multicolumn{6}{|c|}{ Travels during the last year } \\
\cline { 2 - 10 } & $\mathrm{N}$ & $\%$ & $\mathrm{~N}$ & $\%$ & $\mathrm{~N}$ & $\%$ & $\mathrm{~N}$ & $\%$ \\
\hline Nealthy & 9 & 5.1 & 60 & 34.3 & 106 & 60.6 & $\mathbf{1 7 5}$ & $\mathbf{3 3 . 6}$ \\
\hline $\begin{array}{c}\text { With average } \\
\text { income }\end{array}$ & 25 & 8.1 & 123 & 39.8 & 161 & 52.1 & $\mathbf{3 0 9}$ & $\mathbf{5 9 . 3}$ \\
\hline $\begin{array}{c}\text { Low income }+ \\
\text { poor }\end{array}$ & 9 & 24.3 & 12 & 32.4 & 16 & 43.2 & $\mathbf{3 7}$ & $\mathbf{7 . 1}$ \\
\hline Total & $\mathbf{4 3}$ & $\mathbf{8 . 3}$ & $\mathbf{1 9 5}$ & $\mathbf{3 7 . 4}$ & $\mathbf{2 8 3}$ & $\mathbf{5 4 . 3}$ & $\mathbf{5 2 1}$ & $\mathbf{1 0 0}$ \\
\hline $\begin{array}{c}\text { Chi-squared } \\
\text { test }\end{array}$ & $\mathbf{d f = 4 , ~ p = 0 . 0 0 2}$ & & & & \multicolumn{2}{|c|}{ Total } \\
\hline
\end{tabular}

Source: Author's elaboration based on the conducted research

The authors are aware of the existence of other economic factors which may have an influence on tourism activity of subjects and which have not been analysed in detail in the paper. Travelling costs belong to these factors. They depend on the prices of goods and tourism services, duration of stay and distance of the destination from the place of residence. Literature also mentions consumption-related costs of tourism activity. Senyszyn $^{23}$ enumerates examples of such costs: cost of vaccination, cost of visa, cost of passport update, cost of purchasing products which would not be bought but for the

\footnotetext{
${ }^{23}$ Senyszyn J., Koszty okołokonsumpcyjne i ekonomiczna efektywność konsumpcji turystycznej [in:] Turystyka w środowisku społecznym i gospodarczym, Zeszyty Naukowe AWF Kraków nr 75, Kraków 1998.
} 
journey and which will probably not be used later. The group of economic factors also includes costs of currency exchange, savings and buyer's credit rating.

\section{SOCIAL DETERMINANTS OF TOURISM ACTIVITY}

The functioning in social groups is integrally related to the socialisation and upbringing process. The environment one is raised in plays a very important role in the development of one's attitudes, including the attitude to tourism activity. Family and school belong to educational environments of special importance.

Family plays the role of priority importance in society. This has already been emphasised by ancient philosophers, e.g. Aristotle. August Comte, the father of sociology, considered the family to be the most important social group on which the entire community is based. Contemporary sociologists, pedagogues and psychologists mention and discuss various functions fulfilled by the family in diverse spheres of life. The socialising and educational function is a very important function, along with other, such as material and economic, sexual, control, emotional and expressive, and cultural functions ${ }^{24}$. The parents' duty to bring children up so that they would learn how to use their free time in a valuable way in order to develop their proper habits in this respect belongs to this function. A particular role of the family as the organiser of free time activities is stressed by, for example, Tyszkowa ${ }^{25}$, Kulesza ${ }^{26}$, Wolańska ${ }^{27}$, Woźniak ${ }^{28}$, Tabor $^{29}$, Delekta $^{3031}$.

Children develop their ability to organise their leisure time by watching examples shown by parents. The proper free time management has several functions: it helps regenerate in physical and mental spheres, allows for resting from daily chores, develops interests and personality, is conducive to entertainment, play and self-fulfilment, and brings joy. It seems that the practising of tourism meets these conditions.

Marcinkowski ${ }^{32}$ and Delekta ${ }^{33}$ note that cultural traditions of a family determine the level of tourism activity and personal preferences in this area in a particular manner. The

\footnotetext{
${ }^{24}$ Tyszka Z., Rodzina w świecie wspótczesnym - jej znaczenie dla jednostki i społeczeństwa [in:] Pedagogika społeczna, Pilch T., Lepalczyk I. (ed.), Wydawnictwo Żak, Warszawa 1995.

${ }^{25}$ Tyszkowa M., Aktywność i działalność dzieci i młodzieży, Wydawnictwa Szkolne i Pedagogiczne, Warszawa 1990.

${ }^{26}$ Kulesza W., Rodzina jako źródto kształtowania się i wyboru turystycznych form wypoczynku w środowisku studenckim [in:] Społeczno-pedagogiczne problemy turystyki, Malinowski J. (ed.), Instytut Turystyki, Warszawa 1988.

${ }^{27}$ Wolańska T., Rekreacja a codzienne życie $w$ rodzinie [in:] Rekreacja i turystyka $w$ rodzinie, Łobożewicz T., Wolańska T. (ed.), Wydawnictwo Estrella, Warszawa 1994.

${ }^{28}$ Woźniak E., Pedagogika czasu wolnego Aleksandra Kamińskiego [in:] Koncepcjaczasu wolnego Aleksandra Kamińskiego, Walczak M. (ed.), Wydawnictwo WSP,Zielona Góra 1996.

${ }^{29}$ Taboł S., Wplyw rodziny na wykorzystanie czasu wolnego, „Życie Szkoły” nr 3, 2002.

${ }^{30}$ Delekta A., Determinanty aktywności..., op. cit.

${ }^{31}$ Delekta A., Spoleczne determinanty aktywności turystycznej studentów krakowskiego ośrodka akademickiego, Humanities and SocialSciences, vol. XIX, nr 21 (4), Wydawnictwo Politechniki Rzeszowskiej, Rzeszów 2014, s. 25-35.

${ }^{32}$ Marcinkowski M., Zachowania wolnoczasowe wskaźnikiem jakości życia [in:] Czas wolny. Rekreacja. Turystyka. Hotelarstwo. Żywienie, Siwiński W., Tauber R. D., Mucha-Szajek E. (ed.), Wydawnictwo Wyższej Szkoły Hotelarstwa i Gastronomii w Poznaniu, Poznań 2003.

${ }^{33}$ Delekta A., Spoleczne determinanty..., op. cit.
} 
example given by parents will influence how active the child will be in the sphere of tourism in future and what scale his or her activity will take.

Table 3. Tourism activity with parents in the past vs. travels during the previous year (with accommodation for at least one night)

\begin{tabular}{|c|c|c|c|c|c|c|c|c|}
\hline \multirow{3}{*}{$\begin{array}{l}\text { My parents took me to } \\
\text { places outside our } \\
\text { place of permanent } \\
\text { residence for tourist } \\
\text { purposes: }\end{array}$} & \multicolumn{8}{|c|}{$\begin{array}{l}\text { Tourism activity during the last year (with } \\
\text { accommodation) }\end{array}$} \\
\hline & \multicolumn{2}{|c|}{ None at all } & \multicolumn{2}{|c|}{$\begin{array}{c}\text { Once or } \\
\text { twice }\end{array}$} & \multicolumn{2}{|c|}{$\begin{array}{c}\text { Multiple } \\
\text { times }\end{array}$} & \multicolumn{2}{|c|}{ Total } \\
\hline & $\mathrm{N}$ & $\%$ & $\mathrm{~N}$ & $\%$ & $\mathrm{~N}$ & $\%$ & $\mathbf{N}$ & $\%$ \\
\hline Very often & 6 & 6.45 & 29 & 31.18 & 58 & 62.37 & 93 & 17.9 \\
\hline Often & 11 & 4.95 & 83 & 37.39 & 128 & 57.66 & 222 & 42.6 \\
\hline Rarely & 16 & 9.76 & 89 & 54.27 & 59 & 35.98 & 164 & 31.5 \\
\hline Not at all & 17 & 40.48 & 9 & 21.43 & 16 & 38.1 & 42 & 8.1 \\
\hline Total & 50 & 9.6 & 210 & 40.3 & 261 & 50.1 & 521 & 100 \\
\hline Chi-squared test & \multicolumn{8}{|c|}{$\mathrm{df}=6, \mathrm{p}<0.001$} \\
\hline
\end{tabular}

Source: Author's elaboration based on the conducted research

Research shows that students who frequently travelled with their parents when they were children or adolescents exhibit the highest level of tourism activity (62\%). Ten percent of subject never travel and $40 \%$ of this group declare that they never practised tourism with their family.

A statistical analysis has shown that the level of statistical significance $p$ is lower than 0.001 for the analysed variables. Therefore, there is a statistically significant dependence between tourism activity with parents in the past and the frequency of travels of the examined students during the year preceding the date of research if it is assumed that each travel included accommodation in the visited area for at least one night (table 3 ).

The influence of the school is important for the development of interest in tourism. As a social and educational environment, school takes a series of actions which influence complex personal development, including attitude to free time and its management in a valuable way. School is often the environment in which the idea of tourism and sightseeing is pursued both in the form of regular classes and out-of-curriculum classes. As the organiser of excursions, field classes, educational paths or quests, the school is aware that these have an impact on positive feelings towards the social and natural environment, develop thinking, attention and perceptiveness, and encourage drawing personal conclusions. Possibilities of developing tourism-related attitudes by the school are analysed, for example, by Kamiński ${ }^{3435}$, Woźniak ${ }^{36}$, Walczak ${ }^{37}$, Denek ${ }^{38}$ and other researchers.

\footnotetext{
${ }^{34}$ Kamiński A., Czas wolny i jego problematyka społeczno-wychowawcza, Zakład Narodowy im. Ossolińskich, Wrocław 1965.

${ }^{35}$ Kamiński A., Nauczanie $i$ wychowanie metodą harcerska, Związek Harcerstwa Rzeczypospolitej, Warszawa 2001.
} 
There are many benefits of tourism practised through school. JoëlZaffran ${ }^{39}$ emphasises that the way pupils spend their free time has a considerable impact on the course of their educational career. Another advantage is the possibility of participation in tourism of children and young people who are unable to travel with their parents.

In order to specify the influence of school tourism on tourism activity of a young person, it was verified how often (during a year) schools attended in the past by the examined students organised excursions. Research results indicate that the subjects who had opportunities to participate in various forms of tourism organised by the school exhibit a higher level of participation in tourism.

Table 4. School tourism and tourism activity of students during the previous year (with accommodation for at least one night)

\begin{tabular}{|c|c|c|c|c|c|c|c|c|}
\hline \multirow{3}{*}{$\begin{array}{l}\text { The school organised } \\
\text { travels for my class } \\
\text { (on average during a } \\
\text { year): }\end{array}$} & \multicolumn{8}{|c|}{ Tourism activity during the last year (with accommodation) } \\
\hline & \multicolumn{2}{|c|}{ None at all } & \multicolumn{2}{|c|}{$\begin{array}{c}\text { Once or } \\
\text { twice }\end{array}$} & \multicolumn{2}{|c|}{$\begin{array}{c}\text { Multiple } \\
\text { times }\end{array}$} & \multicolumn{2}{|c|}{ Total } \\
\hline & $\mathrm{N}$ & $\%$ & $\mathrm{~N}$ & $\%$ & $\mathrm{~N}$ & $\%$ & $\mathbf{N}$ & $\%$ \\
\hline Several times & 16 & 6.87 & 79 & 33.91 & 138 & 59.23 & 233 & 44.7 \\
\hline Once a year & 29 & 14.29 & 73 & 35.96 & 101 & 49.75 & 203 & 39 \\
\hline Once a few years & 6 & 8.6 & 30 & 42.86 & 34 & 48.57 & 70 & 13.4 \\
\hline None at all & 5 & 33.3 & 6 & 40 & 4 & 26.67 & 15 & 2.9 \\
\hline Total & 56 & 10.7 & 188 & 36.1 & 277 & 53.2 & 521 & 100 \\
\hline Chi-squared test & \multicolumn{8}{|c|}{$\mathrm{df}=6, \mathrm{p}=\mathbf{0 . 0 0 5}$} \\
\hline
\end{tabular}

Source: Author's elaboration based on the conducted research

As already mentioned, it is mainly family home and school which should educate children and teenagers to spend their free time in a valuable way, including on tourism activity. The integration of a family and school community creates multiple opportunities for developing an active, healthy and cultured lifestyle. However, it is beyond any doubt that extracurricular activities and out-of-school classes are very good for this purpose as the rule of voluntariness is best pursued there. The objective of such classes is to shape and develop interests and talents of young people, satisfy and sublimate needs as well as create new patterns. Apart from school, other organisations which conduct classes in tourism and sightseeing are the Polish Scouting and Guiding Association, the Scouting Association of the Republic of Poland and the Polish Tourist and Sightseeing Society.

\footnotetext{
${ }^{36}$ Woźniak E., op. cit.

${ }^{37}$ Walczak M., Koncepcja czasu wolnego Aleksandra Kamińskiego, Wydawnictwo WSP, Zielona Góra 1996.

${ }^{38}$ Denek K., W kręgu edukacji, krajoznawstwa i turystyki w szkole, Wydawnictwo Eruditus, Poznań 2000.

${ }^{39}$ Zaffran J., Le temps de l'adolescence. Entre contrainteetliberté, Presses universitaires de Rennes, Rennes 2010.
} 
Research indicates that membership in these organisations and their activities as defined in statutes are important factors which affect the level of tourism activity of examined subjects (table 5). This is suggested by a very low value of $p(\mathrm{p}<0.0001)$.

Table 5. The influence of student's membership in tourism organisations and travels during the previous year (with accommodation for at least one night)

\begin{tabular}{|l|c|c|c|c|c|c|c|c|}
\hline \multirow{2}{*}{$\begin{array}{l}\text { Membership in a tourism } \\
\text { organisation }\end{array}$} & \multicolumn{6}{|c|}{ Tourism activity during the last year (with } \\
accommodation) \\
\cline { 2 - 10 } & None at all & \multicolumn{2}{|c|}{$\begin{array}{c}\text { Once or } \\
\text { twice }\end{array}$} & \multicolumn{2}{|c|}{$\begin{array}{c}\text { Multiple } \\
\text { times }\end{array}$} & \multicolumn{2}{|c|}{ Total } \\
\cline { 2 - 10 } & $\mathrm{N}$ & $\%$ & $\mathrm{~N}$ & $\%$ & $\mathrm{~N}$ & $\%$ & $\mathrm{~N}$ & $\%$ \\
\hline Yes & 10 & 13.2 & 19 & 25 & 47 & 61.8 & $\mathbf{7 6}$ & $\mathbf{1 4 . 6}$ \\
\hline No & 55 & 12.4 & 220 & 49.4 & 170 & 38.2 & $\mathbf{4 4 5}$ & $\mathbf{8 5 . 4}$ \\
\hline Total & $\mathbf{6 5}$ & $\mathbf{1 2 . 5}$ & $\mathbf{2 3 9}$ & $\mathbf{4 5 . 9}$ & $\mathbf{2 1 7}$ & $\mathbf{4 1 . 7}$ & $\mathbf{5 2 1}$ & $\mathbf{1 0 0}$ \\
\hline Chi-squared test & \multicolumn{7}{|c|}{$\mathbf{d f = 2 , p < 0 . 0 0 1}$} \\
\hline
\end{tabular}

Source: Author's elaboration based on the conducted research

\section{CONCLUSIONS}

The results of qualitative research show that young people treat tourism activity as an important part of their daily life rather than a short escape from the daily life or detachment from the reality. Travelling is a basis of many life spheres for them. It is a form of learning, a way for personal development, a source of professional career. Finally, it is also an opportunity to make contacts with representatives of other cultures. One may have an impression that social and cultural consequences of journeys by young people become more important that those economic ones. The stories of subjects who are active tourists include memories of family excursions from the past. The issue of the attitude of openness to the world and people developed in childhood also appears. Such an attitude is associated with courage to go to new destinations. The results of the statistical analysis of the material collected in quantitative research confirm this dependence and give a higher rank to "tourism activity with parents in the past" than to the analysed economic factors (material situation of a student and his or her family). This is suggested by a high value of Tschuprow's T measure of association for the "frequency of travels with parents" variable correlated with the level of tourism activity. A high value of the measure of association is the evidence of the considerable strength of the relation between the analysed variables. Therefore, hypothesis $\mathrm{H} 2$ should be rejected. According to this hypothesis, it is the economic factors which determine participation in tourism in a strongest way.

The application of the chi-squared test of independence for the statistical analysis of quantitative material enabled the author to determine the relation between tourism activity of students and some economic and social factors. It was proven that there is a statistically significant dependence between the student's material situation and that of his or her family members and the level of participation in tourism. It was also evidenced that there is a statistically significant relation between "family tourism" and "school tourism" and the level of students' tourism activity. Therefore, hypothesis H1 can be assumed according 
to which there is a statistically significant relation between the analysed social and economic factors and the level of tourism activity of examined students from the academic centre of Krakow.

The lack of free time, the lack of appropriate company, financial situation and the lack of eagerness to travel are the greatest inhibitors or barriers to tourism activity of the examined students. Mróz and Rettinger ${ }^{40}$ also point at similar restrictions in their research.

\section{SUMMARY}

Reports of the World Tourism Organisation and author's own research show that young people travel to places which are not very popular among average tourists much more frequently, for a longer time and with greater eagerness. Student tourism is thus an important segment of the tourism market. It is noted that tourism is less and less frequently treated as a luxury product and becomes an indispensable element of the lifestyle of almost every young person. Economic factors undoubtedly have a considerable impact on the level of tourism activity, as manifested by research but a low level of income does not disqualify anyone from participation in tourism. Research shows that tourism need not entail huge expenses, especially when a tourist is a student and the standard of services is not high. It is commonly believed that economic factors belong to the most important factors affecting the tourism activity of people. But the conducted research does not confirm this view. Tourism experience from students' family home turned out to be the most important factor.

\section{REFERENCES}

[1] Alejziak W., Determinanty $i$ zróżnicowanie społeczne aktywności turystycznej, Wydawnictwo AWF, Kraków 2009.

[2] Andrykiewicz-Feczko Z., Psychospołeczne podstawy wartościowania cech jakości produktu, Raport nr III.41 z badań na temat „Relacje między jakością towarów rynkowych a potrzebami konsumentów”, Kraków 1986.

[3] Boje, D. M., The Storytelling Organization: A Study of Story Performance in an Office-Supply Firm, Administrative Science Quarterly, 36(1), 1991, s.106-126.

[4] Boje, D. M. i Tourani, N. Storytelling, czyli o materialności praktyk opowiadania", [w:] Badania jakościowe. Podejściaiteorie, Jemielniak, D., WydawnictwoNaukowe PWN, Warszawa 2012.

[5] Borkowski K., Pilot a grupa [w:] Kompendium pilota wycieczek, red. Kruczek Z., Wydawnictwo Proksenia, Kraków 2000.

[6] BoyerM., Le tourisme, PressesUniversitaires de Lyon, Lyon 1999.

[7] Chudoba T., Wprowadzenie do teorii turystyki, Wydawnictwo AWF, Warszawa 1998

[8] CooperC., Fletcher J., Gibler D., Wanhill S., Tourism Principles and Practice, Pitman Publishing, Surrey, 1993.

\footnotetext{
${ }^{40}$ Mróz F., Rettinger R., Turystyka aktywna a spędzanie czasu wolnego przez studentów kierunku „Turystyka i rekreacja” wybranych szkół wyższych w Małopolsce, [in:] Stasiak A., Śledzińska J. i Włodarczyk B. (ed.), Wczoraj, dziś i jutro turystyki aktywnej i specjalistycznej, Wydawnictwo PTTK „Kraj”, Warszawa 2015, s. 373-386.
} 
[9] Delekta A., Determinanty aktywności i destynacji turystycznych studentów dużego $i$ małego ośrodka akademickiego, Wydawnictwo Naukowe Uniwersytetu Pedagogicznego, Kraków 2013.

[10] Delekta A., Społeczne determinanty aktywności turystycznej studentów krakowskiego ośrodka akademickiego, Humanities and SocialSciences, vol. XIX, nr 21 (4), Wydawnictwo Politechniki Rzeszowskiej, Rzeszów 2014, s. 25-35

[11] Denek K., $W$ kregu edukacji, krajoznawstwa $i$ turystyki $w$ szkole, Wydawnictwo Eruditus, Poznań 2000.

[12] Kamiński A., Czas wolny i jego problematyka społeczno-wychowawcza, Zakład

Narodowy im. Ossolińskich, Wrocław 1965.

[13] Kamiński A., Nauczanie $i$ wychowanie metoda harcerska, Związek Harcerstwa Rzeczypospolitej, Warszawa 2001.

[14] Kulesza W., Rodzina jako źródło kształtowania się i wyboru turystycznych form wypoczynku w środowisku studenckim [w:] Społeczno-pedagogiczne problemy turystyki, red. J. Malinowski, Instytut Turystyki, Warszawa 1988.

[15] Łopaciński K., Aktywność turystyczna młodzieży akademickiej, Problemy Turystyki nr 2, Warszawa 1986.

[16] Łopaciński K., Poziom aktywności turystycznej studentów [w:] Społecznopedagogiczne problemy turystyki, red. J. A. Malinowski, Instytut Turystyki, Warszawa 1988.

[17] Marcinkowski M., Zachowania wolnoczasowe wskaźnikiem jakości życia [w:] Czas wolny. Rekreacja. Turystyka. Hotelarstwo. Żywienie, red. Siwiński W., Tauber R. D., Mucha-Szajek E., Wydawnictwo Wyższej Szkoły Hotelarstwa i Gastronomii w Poznaniu, Poznań 2003.

[18] Mróz F., Rettinger R., Turystyka aktywna a spędzanie czasu wolnego przez studentów kierunku ,Turystyka i rekreacja” wybranych szkót wyższych w Małopolsce, [w:] Stasiak A., Śledzińska J. i Włodarczyk B. (red.), Wczoraj, dziś $i$ jutro turystyki aktywnej $i$ specjalistycznej, Wydawnictwo PTTK „Kraj”, Warszawa 2015, s. 373-386.

[19] Różycki P., Determinanty aktywności turystycznej młodzieży, Problemy Turystyki, nr 1-4, 2006.

[20] Senyszyn J., Koszty okołokonsumpcyjne i ekonomiczna efektywność konsumpcji turystycznej [w:] Turystyka w środowisku spotecznym $i$ gospodarczym, Zeszyty Naukowe AWF Kraków nr 75, Kraków 1998.

[21] Skorny Z., Mechanizmy regulacyjne ludzkiego działania, Wydawnictwo Naukowe PWN, Warszawa 1989.

[22] Taboł S., Wpływ rodziny na wykorzystanie czasu wolnego, „Życie Szkoły" nr 3, 2002.

[23] Tyszka Z., Rodzina w świecie współczesnym - jej znaczenie dla jednostki $i$ społeczeństwa [w:] Pedagogika społeczna, red. T. Pilch, I. Lepalczyk, Wydawnictwo Żak, Warszawa 1995.

[24] Tyszkowa M., Aktywność i działalność dzieci i młodzieży, Wydawnictwa Szkolne i Pedagogiczne, Warszawa 1990. 
[25] UNWTO, TourismHightlights, Edition 2016.

[26] Urry J., Spojrzenie turysty, Wydawnictwo Naukowe PWN, Warszawa 2007.

[27] Walczak M., Koncepcja czasu wolnego Aleksandra Kamińskiego, Wydawnictwo WSP, Zielona Góra 1996.

[28] Wartecka-Ważyńska A., Rola wybranych organizacji społecznych $w$ ksztaltowaniu aktywności turystycznej młodzieży, Turystyka i hotelarstwo, nr 8, 2005.

[29] Wasiak H., Czynniki ksztaltujace konsumpcje w dziedzinie turystyki, wypoczynku $i$ innych form rekreacji $w$ układach regionalnych, Prace Naukowe nr 130 AE we Wrocławiu, Wrocław 1978.

[30] Wolańska T., Rekreacja a codzienne życie $w$ rodzinie [w:] Rekreacja $i$ turystyka $w$ rodzinie, red. T. Łobożewicz, T. Wolańska, Wydawnictwo Estrella, Warszawa 1994.

[31] Woźniak E., Pedagogika czasu wolnego Aleksandra Kamińskiego [w:] Koncepcja czasu wolnego Aleksandra Kamińskiego, red. M. Walczak, Wydawnictwo WSP, Zielona Góra 1996.

[32] Zaffran J., Le temps de l'adolescence. Entre contrainteetliberté, Presses universitaires de Rennes, Rennes 2010.

\section{SPOLECZNO-EKONOMICZNE UWARUNKOWANIA AKTYWNOŚCI \\ TURYSTYCZNEJ KRAKOWSKIEJ MLODZIEŻY UNIWERSYTECKIEJ}

Badania identyfikują uwarunkowania aktywności turystycznej młodzieży uniwersyteckiej, szczególnie skupiając się na analizie niektórych czynników społecznych i ekonomicznych. Postawiono hipotezę (H1) o występowaniu istotnej zależności między wybranymi czynnikami społecznymi i ekonomicznymi a poziomem aktywności turystycznej badanych studentów krakowskiego ośrodka akademickiego. Postanowiono zweryfikować również hipotezę $(\mathrm{H} 2)$ głosząca, że czynniki ekonomiczne mają największy wpływ na uczestnictwo w turystyce. Badania zostały przeprowadzone $\mathrm{z}$ wykorzystaniem metod ilościowych i jakościowych. Badania ilościowe przeprowadzono metodą sondażu diagnostycznego na 521 studentach losowo wybranych uczelni krakowskiego ośrodka akademickiego. Badania jakościowe zostały wykonane w oparciu o założenia metody „storytellingu”. Ta część badań miała postać wywiadów ze studentami prezentującymi różny poziom aktywności turystycznej. Szczegółowym wywiadom poddano po 4 studentów z każdego z założonych typów. Analiza statystyczna oparta na metodach statystycznych (test niezależności chi-kwadrat, współczynnik zbieżności T-Czuprowa), pozwala na przyjęcie hipotezy H1 oraz nakazuje odrzucić hipotezę H2.

Słowa kluczowe:uwarunkowania aktywności turystycznej,aktywność turystyczna, młodzież akademicka, turystyka studencka, storytelling.

DOI:10.7862/rz.2016.hss.39

Przesłano do redakcji: styczeń 2016

Przyjęto do druku: wrzesień 2016 